\title{
Microplastic pollution on Caribbean beaches in the Lesser Antilles
}

\author{
Thijs Bosker ${ }^{\mathrm{a}, \mathrm{b}, *}$, Lucia Guaita ${ }^{\mathrm{a}}$, Paul Behrens ${ }^{\mathrm{a}, \mathrm{b}}$ \\ a Leiden University College, Leiden University, P.O. Box 13228, 2501 EE The Hague, The Netherlands \\ b Institute of Environmental Sciences, Leiden University, P.O. Box 9518, 2300 RA Leiden, The Netherlands
}

\section{A R T I C L E I N F O}

\section{Keywords:}

Caribbean

Lesser Antilles

Microplastics

Beach sediment

Plastic pollution

\begin{abstract}
A B S T R A C T
Here we investigate microplastics contamination on beaches of four islands of the Lesser Antilles (Anguilla, St. Barthélemy, St. Eustatius and St. Martin/Maarten). These islands are close to the North Atlantic subtropical gyre, which contains high levels of microplastics. On average $261 \pm 6$ microplastics/kg of dry sand were found, with a maximum of $620 \pm 96$ microplastics on Grandes Cayes, Saint Martin. The vast majority of these microplastics ( $>$ 95\%) were fibers. Levels of microplastics differed among islands, with significantly lower levels found in St. Eustatius compared to the other Islands. No difference in microplastic levels was found between windward and leeward beaches. Our research provides a detailed study on microplastics on beaches in the Lesser Antilles. These results are important in developing a deeper understanding of the extent of the microplastic challenge within the Caribbean region, a hotspot of biodiversity.
\end{abstract}

\section{Introduction}

Microplastics (pieces of plastics $<5 \mathrm{~mm}$ ) are a group of contaminants of emerging concern, which are now ubiquitous in the environment (Andrady, 2011; Cole et al., 2011; Lots et al., 2017; Nizzetto et al., 2016). Two types of microplastics are commonly distinguished in the literature: primary and secondary microplastics. Primary microplastics are added to household products or used in industry, and are often uniform in shape (Browne et al., 2011; Rochman et al., 2015; van Wezel et al., 2015). Secondary microplastics are formed when larger pieces of plastic break down in the environment due to ultraviolet (UV) exposure and weathering (Andrady, 2011). This results in fragmentation into smaller pieces of plastics (Andrady, 2011; Cole et al., 2011). Consequently, there is a large range in physico-chemical characteristics of microplastics. They exist in different shapes (e.g., fibers, microspheres, fragments) (Cole et al., 2011; Ivar do Sul and Costa, 2014; Naidoo et al., 2015; Wright et al., 2013), size ranges (from the nano- to mm-range) (Andrady, 2011; Cole et al., 2011; Costa et al., 2010; Ivar do Sul and Costa, 2014; Ter Halle et al., 2016; Wright et al., 2013) and chemical constituents (e.g., polyethylene, polypropylene, polyvinylchloride and polystyrene) (Andrady, 2011; Browne et al., 2010; Engler, 2012).

Microplastics are easily ingested by organisms due to their small size (Cole and Galloway, 2015; Desforges et al., 2015; Setälä et al., 2014; Van Cauwenberghe et al., 2015; Vendel et al., 2017). In addition, laboratory experiments have found adverse impacts of microplastics, including: decreased survival and reduced fecundity in the marine copepod Tigriopus japonicus (Lee et al., 2013); decreased reproductive output in the marine copepod Calanus helgolandicus (Cole et al., 2015); anomalous embryonic development in the sea urchin Lytechinus variegatus (Nobre et al., 2015); reduced feeding behavior in brine shrimp Artemia franciscana larvae (Bergami et al., 2016); reduced body mass in the langoustine Nephrops norvegicus (Welden and Cowie, 2016); and, tissue damage in the blue mussel Mytilus edulis (von Moos et al., 2012).

The marine environment has been identified as a major sink for microplastics (Cole et al., 2011; Ivar do Sul and Costa, 2014; Woodall et al., 2014). An important factor influencing plastic distribution and accumulation in oceans are ocean currents (Cózar et al., 2017; Law et al., 2010). For example, in the North Atlantic subtropical gyre levels of microplastics exceed 100,000 pieces $/ \mathrm{km}^{2}$ (Eriksen et al., 2014; Law et al., 2010). The North Atlantic subtropical gyre is located close to the Caribbean region, which is the location for this study. A study on microplastic levels in Caribbean surface waters between 1986 and 2008 found an average distribution of 1414 items $/ \mathrm{km}^{2}$, with a peak of 580,000 items $/ \mathrm{km}^{2}$ in May 1997 on the eastern-side of the Bahamas (Law et al., 2010).

Very few studies have investigated microplastics on Caribbean beaches (Ivar Do Sul and Costa, 2007; Monteiro et al., 2018). A study on Columbian beaches, found limited plastics (an average of 3 particles $/ \mathrm{m}$ ) (Acosta-Coley and Olivero-Verbel, 2015). Three earlier studies, focusing on plastic fragments and pellets, found relatively high levels, but in these studies no size definition is provided on the fragments identified (Debrot et al., 1999; Gregory, 1983; Wilber, 1987). In addition, studies on meso- and macroplastics on Aruba (Southern Caribbean)

\footnotetext{
* Corresponding author at: Leiden University College, Leiden University, P.O. Box 13228, 2501 EE The Hague, The Netherlands.

E-mail addresses: t.bosker@luc.leidenuniv.nl (T. Bosker), l.guaita@umail.leidenuniv.nl (L. Guaita), p.a.behrens@luc.leidenuniv.nl (P. Behrens).
} 


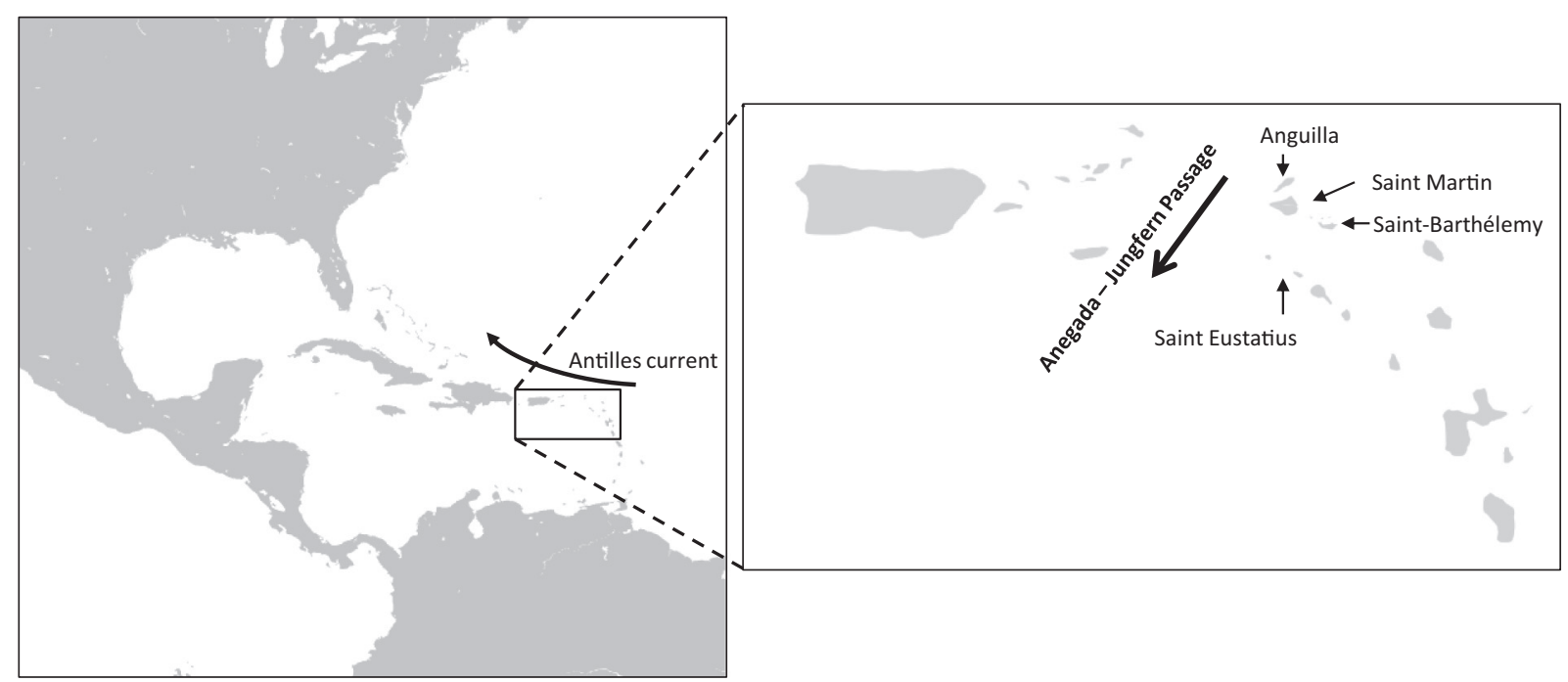

Fig. 1. Figure showing the four Island in the Lesser Antilles region samples, and key currents acting in the proximity of the sampling locations.

found significant variations in composition and quantity of plastics between windward and leeward beaches on the Island (de Scisciolo et al., 2016).

The aim of this study was to increase our understanding on microplastics levels in beach sediment in the Caribbean region. To this end we investigated the level, distribution, and characteristics of microplastics on four Islands of the Lesser Antilles, located in close proximity to the North Atlantic subtropical gyre. This research will contribute to the knowledge on microplastics distribution in this region, ultimately increasing our understanding on how to develop optimal coastal management regulations to protect these ecosystems (Rochman, 2016). This is of importance, as this region has an exceptionally rich biodiversity, making it a biodiversity hotspot for both terrestrial and marine ecosystems (Myers et al., 2000).

\section{Materials and methods}

\subsection{Study site}

This study was conducted on four volcanic islands of the Lesser Antilles: Anguilla, St. Barthélemy, St. Eustatius and St. Martin (Fig. 1), which are located near the North Atlantic subtropical gyre. Part of the South Atlantic water mass is deflected towards the Leeward Islands and enters the Caribbean Sea through the Anegada-Jungfern Passage (Fratantoni et al., 1997; Osborne et al., 2014) (Fig. 1). Although the prevailing winds on the Lesser Antilles are east-north-easterly, there is a bimodal annual pattern, with similar frequencies for easterly and eastnorth-easterly winds (Chadee and Clarke, 2014). The Caribbean region is a highly exposed area to seasonal extreme events such as tropical hurricanes, which have intensified and occurred with a higher frequency in recent years (Bernal et al., 2016).

\subsection{Sampling and extraction procedures}

\subsubsection{Beach sampling}

A total of 21 beaches over the four islands were sampled during June 2016 (Fig. 2; Table S1). For each beach, samples were collected on the same day. Prior to sampling, site selection was conducted using an online mapping program (www.mapcustomizer.com). Accessibility was then checked using satellite imagery (Google Earth version 7.1). For each location GPS coordinates were recorded using a mobile phone application (EzgApps GPS Coordinates Finder version 1.2; projection WGS 84 Web Mercator).

Beach sampling methods were based on a standard operating procedure developed by Besley et al. (2017). In brief, for each sampling location, the high-tide line (or strandline) was first identified by assessing the end of wet sand marks, debris areas or shell deposition areas. Five samples were collected at each beach, with $20 \mathrm{~m}$ between sampling locations, using a $50 \mathrm{~m}$ measuring tape. A $0.25 \mathrm{~m}^{2}$ quadrat was positioned at the center of each of the interval points. Sand from the top $5 \mathrm{~cm}$ was collected from the corners and center of the quadrat using a metallic spoon and five rulers. Next, the sand was sieved through a $5 \mathrm{~mm}$ metallic sieve and collected in a clean plastic zip-lock bag. The sampling equipment was then rinsed in sea water and reused for further samples. Details on the sampling beaches, including beach type, beach management and other features are summarized in Table S2.

\subsubsection{Extraction}

Extraction was conducted at the laboratory facilities of the Caribbean Netherlands Science Institute (CNSI) on St. Eustatius. A density separation method was used, as described in Besley et al, (2017). Briefly, $100 \mathrm{~g}$ (wet weight) of sand was dried at $60^{\circ} \mathrm{C}$ for $48 \mathrm{~h}$. Next, the $50 \mathrm{~g}$ (dry weight) of sand was added in a conical flask containing $200 \mathrm{~mL}$ of fully-saturated $\mathrm{NaCl}$ solution ( $358.9 \mathrm{~g}$ salt/L). The $\mathrm{NaCl}$ solution was filtered using a $47 \mathrm{~mm}$ Millipore $0.45 \mu \mathrm{m}$ filter paper (Fisher Scientific, the Netherlands) to remove impurities and debris deriving from the salt. This suspension was then spun at $900 \mathrm{rpm}$ for 2 min using a magnetic stirrer. The sand was left to settle for a minimum of $8 \mathrm{~h}$.

After settling, the supernatant was filtered through a $0.45 \mu \mathrm{m}$ pore filter paper using a vacuum pump. Approximately $100 \mathrm{~mL}$ of the supernatant was poured into the vacuum pump while slowly rotating the conical flask to prevent floating material from sticking to the sides of the flask. The filter paper was then moved to a clean Petri dish and stored. The extraction process was repeated three times for each sample.

To avoid contamination, all equipment used during the extraction process was rinsed with distilled water before usage. All Petri dishes for storage of samples were wiped (Kimberly Clark cellulose wipe, Fisher Scientific, the Netherlands). During the extraction process, all equipment and vessels were covered when they were not in use.

\subsubsection{Visual identification}

The identification of microplastic fibers and particles was performed by following the guidelines developed by Hidalgo-Ruz et al. (2012). For the identification of fibers, three guiding principles were followed to determine whether they were plastics: 1) consistently clear and 


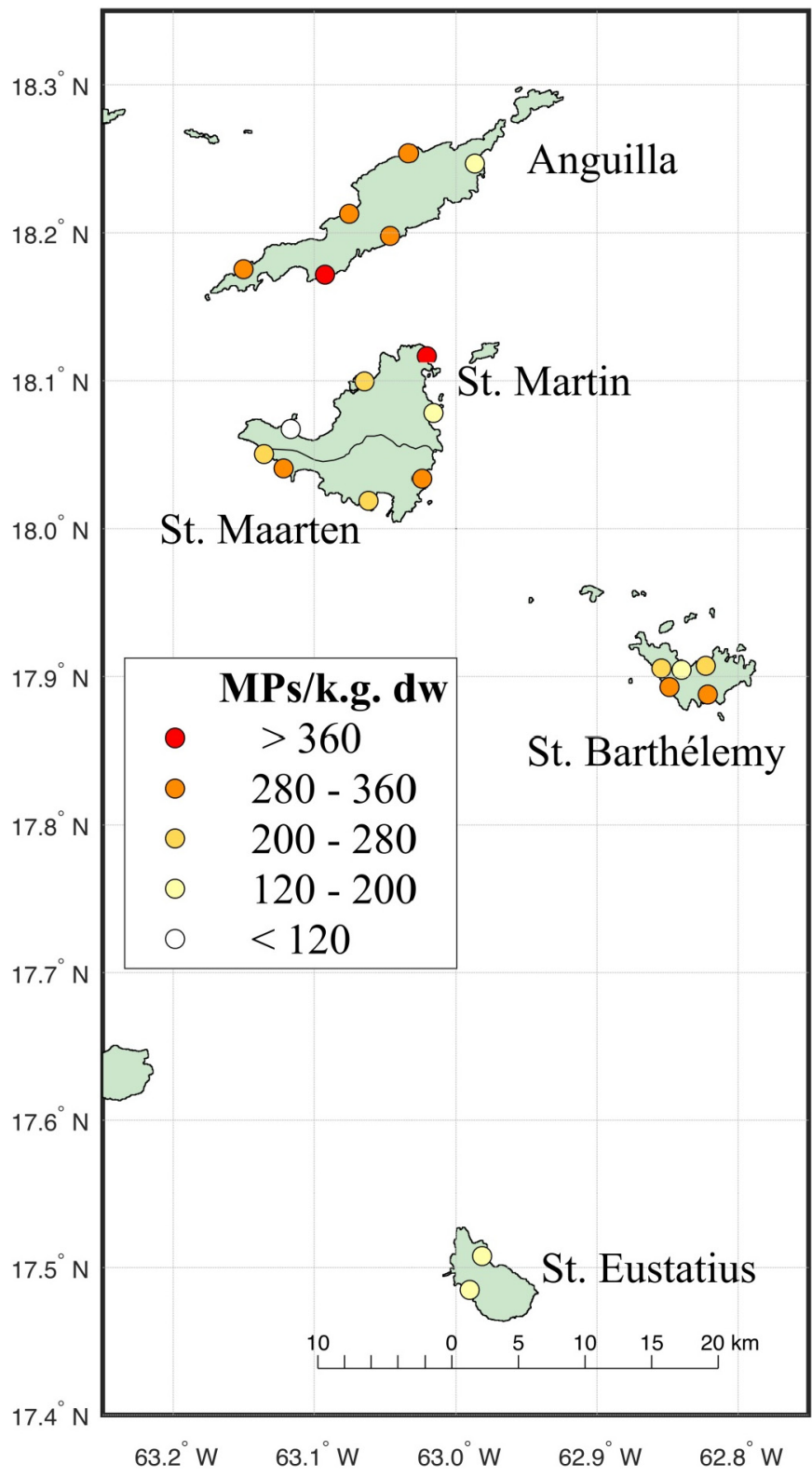

Fig. 2. Microplastic contamination levels across beaches on four islands (Anguilla, St. Barthélemy, St. Eustatius and St. Martin) of the Lesser Antilles. Contamination is reported in number of microplastics per $\mathrm{kg}$ of dry sediment.

homogenous color; 2) no organic matter attached; and, 3) equal thickness throughout their length (Hidalgo-Ruz et al., 2012). For the identification of plastic particles we examined the consistency and homogeneity of colors (Hidalgo-Ruz et al., 2012). Potential microplastics found on filter papers were compared to images of microplastics reported in peer reviewed papers (De Witte et al., 2014; Dekiff et al., 2014; Leslie et al., 2013; Nuelle et al., 2014).

The filter papers were examined under a stereo-microscope (Motic Stereozoom Classmag 41 10-40 $\times$, Fisher Scientific, the Netherlands) at up to $40 \times$ magnification, and the number of microplastics were counted (Besley et al., 2017; Lots et al., 2017). This process allowed for the quantification of microplastics in the range of $0.3-5 \mathrm{~mm}$ (NOAA, 2015). During this identification process, the filter paper was divided into four marked quarters, which were inspected in a clock-wise direction to avoid miscounts. Each filter paper was inspected by at least two researchers until a consensus on the classification of particles was reached.
Table 1

Abundance and type of microplastics in beach sediment. Results are given at different collection locations on the Lesser Antilles. Abundance per location is expressed as the average number of plastics from 5 replicates per kg of dry sediment $( \pm$ SEM). Different letters indicate significant difference among beaches $(p<0.05)$, based on a Kruskal-Wallis test followed by pairwise comparisons. Type of microplastics are catagorised between fibers and other types, and are expressed as a percentage of the total count.

\begin{tabular}{|c|c|c|c|c|c|c|c|}
\hline \multirow[t]{2}{*}{ Location } & \multirow{2}{*}{$\begin{array}{l}\text { Side on } \\
\text { island }\end{array}$} & \multicolumn{4}{|c|}{ Abundance } & \multicolumn{2}{|c|}{ Type of MP } \\
\hline & & \multicolumn{4}{|c|}{ (MPs/kg d.w.) } & $\%$ fiber & $\%$ other \\
\hline \multicolumn{8}{|l|}{ Anguilla } \\
\hline Barnes Bay & Lee & 324 & \pm & 35 & $\mathrm{~b}, \mathrm{e}$ & 100 & 0 \\
\hline Blowing Point & Wind & 396 & \pm & 81 & $\mathrm{~b}, \mathrm{e}$ & 99 & 1 \\
\hline Crocus Bay & Lee & 300 & \pm & 28 & $\mathrm{~b}, \mathrm{~d}, \mathrm{e}$ & 96 & 4 \\
\hline Forest Bay & Wind & 360 & \pm & 110 & $\mathrm{~b}, \mathrm{~d}, \mathrm{e}$ & 100 & 0 \\
\hline Savannah Bay & Wind & 180 & \pm & 52 & $\mathrm{a}, \mathrm{e}$ & 93 & 7 \\
\hline Shoal Bay & Lee & 308 & \pm & 52 & $\mathrm{~b}, \mathrm{~d}, \mathrm{e}$ & 99 & 1 \\
\hline Average Anguilla & & 311 & \pm & 30 & & 98 & 2 \\
\hline \multicolumn{8}{|l|}{ St. Barthelemy } \\
\hline Anse de Public & Lee & 208 & \pm & 29 & $\mathrm{a}$ & 98 & 2 \\
\hline Baie de St. Jean & Lee & 176 & \pm & 21 & $\mathrm{a}, \mathrm{c}, \mathrm{d}$ & 100 & 0 \\
\hline Grand Saline & Wind & 284 & \pm & 74 & a & 96 & 4 \\
\hline Lorient Beach & Lee & 232 & \pm & 41 & $\mathrm{~b}, \mathrm{c}, \mathrm{e}$ & 98 & 2 \\
\hline Shell Beach & Lee & 296 & \pm & 50 & $\mathrm{~b}, \mathrm{~d}, \mathrm{e}$ & 95 & 5 \\
\hline \multicolumn{8}{|l|}{ Barthelemy } \\
\hline \multicolumn{8}{|l|}{ St. Eustatius } \\
\hline Smoke Alley & Lee & 124 & \pm & 16 & $\mathrm{a}, \mathrm{c}$ & 97 & 3 \\
\hline Zeelandia & Wind & 136 & \pm & 28 & $\mathrm{a}, \mathrm{c}$ & 94 & 6 \\
\hline $\begin{array}{l}\text { Average St. Eustatius } \\
\text { St. Martin }\end{array}$ & & 130 & \pm & 6 & & 96 & 5 \\
\hline Anse des Sables & Lee & 68 & \pm & 19 & $\mathrm{a}$ & 100 & 0 \\
\hline Cupecoy Beach & Lee & 232 & \pm & 71 & $\mathrm{~b}, \mathrm{c}, \mathrm{e}$ & 98 & 2 \\
\hline Grand Case & Lee & 208 & \pm & 32 & a & 94 & 6 \\
\hline Grandes Cayes & Wind & 620 & \pm & 96 & $\mathrm{~b}, \mathrm{e}$ & 99 & 1 \\
\hline Guana Bay & Wind & 316 & \pm & 46 & $\mathrm{~b}, \mathrm{~d}, \mathrm{e}$ & 100 & 0 \\
\hline Le Galion & Wind & 124 & \pm & 20 & $\mathrm{a}, \mathrm{c}$ & 87 & 13 \\
\hline Little Bay & Lee & 276 & \pm & 31 & $\mathrm{~b}, \mathrm{~d}, \mathrm{e}$ & 97 & 3 \\
\hline Maho Beach & Lee & 304 & \pm & 39 & $\mathrm{~b}, \mathrm{~d}, \mathrm{e}$ & 100 & 0 \\
\hline Average St. Martin & & 269 & \pm & 59 & & 97 & 3 \\
\hline Overall & & 261 & \pm & 6 & & 97 & 3 \\
\hline
\end{tabular}

\subsection{Data analysis}

Microplastic concentrations for sampling locations were reported in the form of mean \pm SEM calculated from the 5 replicates. The concentrations were expressed in microplastics per $\mathrm{kg}$ of dry weight sediment. We conducted a non-parametric analysis of variance (ANOVA) using a Kruskal-Wallis test, followed by pairwise comparisons on the 21 sampling locations to determine differences among locations (IBM SPSS Statistics v 23). A Mann-Whitney $U$ test was used to compare the differences between leeward and windward beaches. If significant differences were observed, a pairwise comparison was conducted. Significance was set as $\alpha<0.05$.

\section{Results}

Every sample analyzed in this study contained microplastics. The average number of microplastics across all sampling locations was $261 \pm 6$ microplastics/kg dry weight (d.w.) (Table 1), with a median of 276 microplastics $/ \mathrm{kg}$ d.w. Of all the microplastics collected, $97 \%$ were fibers and the remaining $3 \%$ were particles (Table 1 ). There was a wide range in the levels of microplastic among locations. The total number of microplastics ranged from 68 microplastics $/ \mathrm{kg}$ d.w. at Anse des Sables on St. Martin, to 620 microplastics $/ \mathrm{kg}$ d.w. at Grandes Cayes, also on St. Martin (Table 1, Fig. 2). There were significant differences in microplastic abundances among different sampling locations $(p<0.001)$.

When comparing the average levels found on the four different 


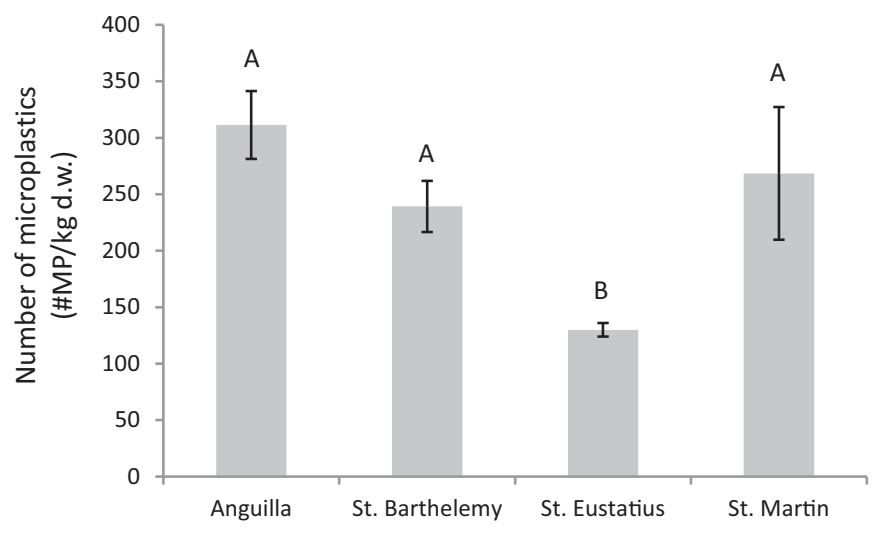

Fig. 3. Average number of microplastics (\#MPs/kg d.w.) in beach sediment on four Lesser Antilles Islands in the Caribbean. Different letters indicate significant difference among beaches $(p<0.10)$, based on a Kruskal-Wallis test followed by pairwise comparisons. Total number of beaches per Island can be found in Table 1.

islands, the highest levels of microplastic were found on Anguilla (311 \pm 30 microplastics $/ \mathrm{kg}$ d.w.), followed by St. Martin (269 \pm 59 microplastics/kg d.w.), St. Barthélemy (239 \pm 23 microplastics $/ \mathrm{kg}$ d.w. $)$ and St. Eustatius (130 \pm 6 microplastics $/ \mathrm{kg}$ d.w. $)$ (Table 1; Fig. 3). The abundance of microplastics on St. Eustatius was lowest, and this difference was marginally significant $(p=0.084)$ compared to Anguilla, St. Martin and St. Barthélemy (Fig. 3).

The abundance of microplastics on the windward beaches was $302 \pm 58$ microplastics $/ \mathrm{kg}$ d.w., while on leeward beaches the average abundance was $235 \pm 22$ microplastics $/ \mathrm{kg}$ d.w. (Fig. 4). The difference in abundance between windward and leeward beaches was not significant $(p=0.34)$.

\section{Discussion}

All samples of beach sand collected in this study contained microplastics. Our average levels are comparable to levels found in other regions. For example, an average of 261 microplastics $/ \mathrm{kg}$ d.w. were found in this study, compared to 248 microplastics $/ \mathrm{kg}$ d.w. in a largescale analysis of microplastics levels on European beaches (Lots et al., 2017). However, the median amount of microplastics per beach was considerably higher on Caribbean beaches, with 276 microplastics $/ \mathrm{kg}$ d.w. versus 143 microplastics/kg d.w. on European beaches (Lots et al., 2017). It should be noted that both studies use the same standardized

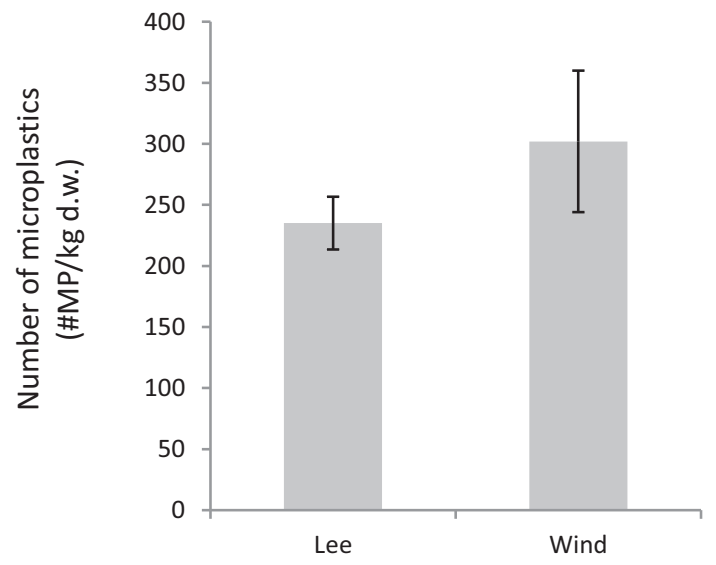

Fig. 4. Average number ( \pm SEM) of microplastics (\#MPs $/ \mathrm{kg}$ d.w.) in beach sediment on Leeward $(n=13)$ and windward $(n=8)$ locations in the Lesser Antilles. No significant difference was observed based on a Mann-Whitney $U$ test. methodology (Besley et al., 2017), and so it is appropriate to make comparisons here.

The levels found herein are difficult to compare to previous Caribbean research due to differences in sampling and extraction procedures (as discussed in detail in Besley et al. 2017). For example, a study in the wider Caribbean region found microplastics levels ranging from 200 to 10,000 microplastics $/ \mathrm{m}^{2}$ (Wilber, 1987). However, this study, which predates the term microplastics, does not identify the size range of the identified plastics used in the study, or the depth at which the samples were taken (Wilber, 1987). Similarly, a study from 1983 which investigated virgin polyethylene pellets found levels of 5000-10,000 pellets per linear meter of beach, but the sampling method was not provided within the paper (Gregory, 1983). Although a different sampling approach was used, we did not find the same, extremely high levels of microplastics per $\mathrm{m}^{2}$ as Gregory (1983) and Wilber (1987).

A more recent paper focused on the Caribbean coast of Colombia found 3 microplastics per linear meter however, this was focused on pellets, and not on fibers (Acosta-Coley and Olivero-Verbel, 2015). Importantly, the large majority of microplastics we found were fibers, and very few were particles. This is in line with other recent studies, for example a previous study on microplastics on European beaches $>90 \%$ of microplastics in beach sand were fibers (Lots et al., 2017). In contrast to beach sediment, a study on microplastics in the water column identified $\sim 75 \%$ of microplastics as fibers (Desforges et al., 2014), while this is only $\sim 40 \%$ in sediment samples (Claessens et al., 2011).

Although we found higher levels of microplastics on windward beaches (302 \pm 58 microplastics/kg d.w.) compared to leeward beaches (235 \pm 22 microplastics $/ \mathrm{kg}$ d.w.), this difference was not statistically significant. Previous studies on the influence of prevailing wind orientation did find more plastic fragments on windward beaches compared to leeward beaches (Monteiro et al., 2018). For example, a study on the Bahamas and Lesser Antilles estimated the level of plastic fragments to be twice as high on windward beaches compared to leeward beaches (Wilber, 1987). A study on Curaçao, in the Southern Caribbean, also found increases (Debrot et al., 1999). Finally, as highlighted in the introduction, a study on meso- and macroplastics on Aruba found significant higher levels of both meso- and macroplastics on windward beaches compared to leeward beaches (de Scisciolo et al., 2016).

Previous research has linked microplastics levels to population density (Pedrotti et al., 2016). The significantly lower levels of microplastics found on the beaches of St. Eustatius could be explained to the lower population of the island, numbering $\sim 3500$ inhabitants. For comparison, Anguilla hosts $\sim 15,000$ inhabitants, St. Martin $\sim 70,000$ inhabitants and St. Barthélemy $\sim 9300$ inhabitants. In addition, tourism has also been linked to increased microplastics contamination. For example, a significantly higher density of microplastics was found on Mexican, Pacific coast beaches with a high density of tourists (Retama et al., 2016). A study of beaches of the Southern Baltic Sea found that tourism and urbanization were probably the most important factors contributing to microplastics concentrations (Graca et al., 2017). In 2016, around 14,300 tourists visited St. Eustatius (CBS, 2017). For comparison, St. Martin welcomed an estimated 2.5 million visitors in 2014 (СTO, 2015), St. Barthélemy an estimated 222,000 in 2016 (sbhonline, 2017) and Anguilla an estimated 71,000 in 2014 (СTO, 2015).

Although our study provides important data on the microplastics concentration in Caribbean beach sand, there are several important avenues for future research. In our opinion, two areas warrant special attention. Firstly, future work should focus on understanding regional microplastic sources. In our current study we only investigated the microplastic levels on beaches, but a study looking at surface and sediment levels in the region is needed to understand the sources and sinks of microplastics. Secondly, we suggest an investigation of microplastic impacts on local, ecologically relevant organisms. 
To conclude, we present a detailed study on microplastics on Caribbean beaches. Microplastics were found in all of the samples taken, with an average of 261 microplastics $/ \mathrm{kg}$ d.w. No significant difference was found between windward and leeward beaches; however, tourism and population of the Island may be an important factor determining microplastics loads. This research provides important baseline data for understanding the distribution of microplastics in the Caribbean region, a hotspot of marine biodiversity (Myers et al., 2000). This understanding can help inform the development of optimal coastal management regulations to protect these ecosystems.

\section{Competing interests}

The authors declare that they have no competing interests.

\section{Funding}

This study was supported by the Gratama Foundation of the Leiden University Fund (project number 2015-08).

\section{Acknowledgements}

We would like to express our thanks to the staff of the Caribbean Netherlands Science Institute (CNSI) at St. Eustatius, and specifically Dr. Johan Stapel, for allowing the use of the laboratory facilities at the CNSI. We also thank Aiken Besley, Lone Mokkenstorm and Froukje Lots for the support during the project.

\section{Appendix A. Supplementary data}

Supplementary data to this article can be found online at https:// doi.org/10.1016/j.marpolbul.2018.05.060.

\section{References}

Acosta-Coley, I., Olivero-Verbel, J., 2015. Microplastic resin pellets on an urban tropical beach in Colombia. Environ. Monit. Assess. 187, 435.

Andrady, A.L., 2011. Microplastics in the marine environment. Mar. Pollut. Bull. 62, 1596-1605.

Bergami, E., Bocci, E., Vannuccini, M.L., Monopoli, M., Salvati, A., Dawson, K.A., Corsi, I., 2016. Nano-sized polystyrene affects feeding, behavior and physiology of brine shrimp Artemia franciscana larvae. Ecotoxicol. Environ. Saf. 123, 18-25.

Occurrence of energetic extreme oceanic events in the Colombian Caribbean coasts and some approaches to assess their impact on ecosystems. Bernal, G., Osorio, A., Urrego, L., Peláez, D. (Eds.), J. Mar. Syst. 164, 85-100. http://dx.doi.org/10.1016/j.jmarsys. 2016.08.007.

Besley, A., Vijver, M.G., Behrens, P., Bosker, T., 2017. A standardized method for sampling and extraction methods for quantifying microplastics in beach sand. Mar. Pollut. Bull. 114, 77-83.

Browne, M.A., Galloway, T.S., Thompson, R.C., 2010. Spatial patterns of plastic debris along estuarine shorelines. Environ. Sci. Technol. 44, 3404-3409.

Browne, M.A., Crump, P., Niven, S.J., Teuten, E., Tonkin, A., Galloway, T., Thompson, R., 2011. Accumulation of microplastic on shorelines worldwide: sources and sinks. Environ. Sci. Technol. 45, 9175-9179.

CBS, 2017. Tourism in the Caribbean Netherlands in 2016.

Chadee, X.T., Clarke, R.M., 2014. Large-scale wind energy potential of the Caribbean region using near-surface reanalysis data. Renew. Sust. Energ. Rev. 30, 45-58.

Claessens, M., De Meester, S., Van Landuyt, L., De Clerck, K., Janssen, C.R., 2011. Occurrence and distribution of microplastics in marine sediments along the Belgian coast. Mar. Pollut. Bull. 62, 2199-2204.

Cole, M., Galloway, T.S., 2015. Ingestion of nanoplastics and microplastics by Pacific oyster larvae. Environ. Sci. Technol. 49, 14625-14632.

Cole, M., Lindeque, P., Halsband, C., Galloway, T.S., 2011. Microplastics as contaminants in the marine environment: a review. Mar. Pollut. Bull. 62, 2588-2597.

Cole, M., Lindeque, P., Fileman, E., Halsband, C., Galloway, T.S., 2015. The impact of polystyrene microplastics on feeding, function and fecundity in the marine copepod Calanus helgolandicus. Environ. Sci. Technol. 49, 1130-1137.

Costa, M.F., Ivar do Sul, J.A., Silva-Cavalcanti, J.S., Araujo, M.C., Spengler, A., Tourinho, P.S., 2010. On the importance of size of plastic fragments and pellets on the strandline: a snapshot of a Brazilian beach. Environ. Monit. Assess. 168, 299-304.

Cózar, A., Martí, E., Duarte, C.M., García-de-Lomas, J., Van Sebille, E., Ballatore, T.J., Eguíluz, V.M., González-Gordillo, J.I., Pedrotti, M.L., Echevarría, F., 2017. The Arctic Ocean as a dead end for floating plastics in the North Atlantic branch of the Thermohaline Circulation. Sci. Adv. 3, e1600582.

CTO, 2015. Caribbean Tourism Organization. Latest Statistics 2014. Barbados.
De Witte, B., Devriese, L., Bekaert, K., Hoffman, S., Vandermeersch, G., Cooreman, K., Robbens, J., 2014. Quality assessment of the blue mussel (Mytilus edulis): comparison between commercial and wild types. Mar. Pollut. Bull. 85, 146-155.

Debrot, A.O., Tiel, A.B., Bradshaw, J.E., 1999. Beach debris in Curaçao. Mar. Pollut. Bull. 38, 795-801.

Dekiff, J.H., Remy, D., Klasmeier, J., Fries, E., 2014. Occurrence and spatial distribution of microplastics in sediments from Norderney. Environ. Pollut. 186, 248-256.

Desforges, J.-P.W., Galbraith, M., Dangerfield, N., Ross, P.S., 2014. Widespread distribution of microplastics in subsurface seawater in the NE Pacific Ocean. Mar. Pollut. Bull. 79, 94-99.

Desforges, J.P.W., Galbraith, M., Ross, P.S., 2015. Ingestion of microplastics by zooplankton in the Northeast Pacific Ocean. Aquat. Toxicol. 69, 320-330.

Engler, R.E., 2012. The complex interaction between marine debris and toxic chemicals in the ocean. Environ. Sci. Technol. 46, 12302-12315.

Eriksen, M., Lebreton, L.C., Carson, H.S., Thiel, M., Moore, C.J., Borerro, J.C., Galgani, F., Ryan, P.G., Reisser, J., 2014. Plastic pollution in the world's oceans: more than 5 trillion plastic pieces weighing over 250,000 tons afloat at sea. PLoS One 9, e111913.

Fratantoni, D.M., Zantopp, R.J., Johns, W.E., Miller, J.L., 1997. Updated bathymetry of the Anegada-Jungfern Passage complex and implications for Atlantic inflow to the abyssal Caribbean Sea. J. Mar. Res. 55, 847-860.

Graca, B., Szewc, K., Zakrzewska, D., Dołęga, A., Szczerbowska-Boruchowska, M., 2017. Sources and fate of microplastics in marine and beach sediments of the Southern Baltic Sea-a preliminary study. Environ. Sci. Pollut. Res. 24, 7650-7661.

Gregory, M.R., 1983. Virgin plastic granules on some beaches of Eastern Canada and Bermuda. Mar. Environ. Res. 10, 73-92.

Hidalgo-Ruz, V., Gutow, L., Thompson, R.C., Thiel, M., 2012. Microplastics in the marine environment: a review of the methods used for identification and quantification. Environ. Sci. Technol. 46, 3060-3075.

Ivar Do Sul, J.A., Costa, M.F., 2007. Marine debris review for Latin America and the Wider Caribbean Region: from the 1970s until now, and where do we go from here? Mar. Pollut. Bull. 54, 1087-1104.

Ivar do Sul, J.A., Costa, M.F., 2014. The present and future of microplastic pollution in the marine environment. Environ. Pollut. 185, 352-364.

Law, K.L., Moret-Ferguson, S., Maximenko, N.A., Proskurowski, G., Peacock, E.E., Hafner, J., Reddy, C.M., 2010. Plastic accumulation in the North Atlantic subtropical gyre. Science 329, 1185-1188.

Lee, K.-W., Shim, W.J., Kwon, O.Y., Kang, J.-H., 2013. Size-dependent effects of micro polystyrene particles in the marine copepod Tigriopus japonicus. Environ. Sci. Technol. 47, 11278-11283.

Leslie, H., Van Velzen, M., Vethaak, A., 2013. Microplastic Survey of the Dutch Environment. IVM Institute for Environmental Studies.

Lots, F.A., Behrens, P., Vijver, M.G., Horton, A.A., Bosker, T., 2017. A large-scale investigation of microplastic contamination: abundance and characteristics of microplastics in European beach sediment. Mar. Pollut. Bull. 123, 219-226.

Monteiro, R.C.P., Ivar Do Sul, J.A., Costa, M.F., 2018. Plastic pollution in islands of the Atlantic Ocean. Environ. Pollut. 238, 103-110.

von Moos, N., Burkhardt-Holm, P., Köhler, A., 2012. Uptake and effects of microplastics on cells and tissue of the blue mussel Mytilus edulis L. after an experimental exposure. Environ. Sci. Technol. 46, 11327-11335.

Myers, N., Mittermeier, R.A., Mittermeier, C.G., da Fonseca, G.A.B., Kent, J., 2000. Biodiversity hotspots for conservation priorities. Nature 403, 853-858.

Naidoo, T., Glassom, D., Smit, A.J., 2015. Plastic pollution in five urban estuaries of KwaZulu-Natal, South Africa. Mar. Pollut. Bull. 101, 473-480.

Nizzetto, L., Langaas, S., Futter, M., 2016. Pollution: do microplastics spill on to farm soils? Nature $537,488$.

NOAA, 2015. Laboratory methods for the analysis of microplastics in the marine environment: recommendations for quantifying synthetic particles in waters and sediments. In: Technical Memorandum NOS-OR\&R-48. National Oceanic and Atmospheric Administration; U.S. Department of Commerce.

Nobre, C.R., Santana, M.F.M., Maluf, A., Cortez, F.S., Cesar, A., Pereira, C.D.S., Turra, A., 2015. Assessment of microplastic toxicity to embryonic development of the sea urchin Lytechinus variegatus (Echinodermata: Echinoidea). Mar. Pollut. Bull. 92, 99-104.

Nuelle, M.-T., Dekiff, J.H., Remy, D., Fries, E., 2014. A new analytical approach for monitoring microplastics in marine sediments. Environ. Pollut. 184, 161-169.

Osborne, A.H., Haley, B.A., Hathorne, E.C., Flögel, S., Frank, M., 2014. Neodymium isotopes and concentrations in Caribbean seawater: tracing water mass mixing and continental input in a semi-enclosed ocean basin. Earth Planet. Sci. Lett. 406, $174-186$.

Pedrotti, M.L., Petit, S., Elineau, A., Bruzaud, S., Crebassa, J.C., Dumontet, B., Martí, E., Gorsky, G., Cózar, A., 2016. Changes in the floating plastic pollution of the Mediterranean Sea in relation to the distance to land. PLoS One 11.

Retama, I., Jonathan, M.P., Shruti, V.C., Velumani, S., Sarkar, S.K., Roy, P.D., RodríguezEspinosa, P.F., 2016. Microplastics in tourist beaches of Huatulco Bay, Pacific coast of southern Mexico. Mar. Pollut. Bull. 113, 530-535.

Rochman, C.M., 2016. Strategies for reducing ocean plastic debris should be diverse and guided by science. Environ. Res. Lett. 11, 041001.

Rochman, C.M., Kross, S.M., Armstrong, J.B., Bogan, M.T., Darling, E.S., Green, S.J., Smyth, A.R., Veríssimo, D., 2015. Scientific evidence supports a ban on microbeads. Environ. Sci. Technol. 49, 10759-10761.

de Scisciolo, T., Mijts, E.N., Becker, T., Eppinga, M.B., 2016. Beach debris on Aruba, Southern Caribbean: attribution to local land-based and distal marine-based sources. Mar. Pollut. Bull. 106, 49-57.

Setälä, O., Fleming-Lehtinen, V., Lehtiniemi, M., 2014. Ingestion and transfer of microplastics in the planktonic food web. Environ. Pollut. 185, 77-83.

shbonline, 2017. Tourism 2016 - The Year in Numbers. https://www.sbhonline.com/ 
forums/showthread.php/90354-Tourism-2016-The-Year-in-Numbers Date last accessed: May 25, 2018.

Ter Halle, A., Ladirat, L., Gendre, X., Goudouneche, D., Pusineri, C., Routaboul, C., Tenailleau, C., Duployer, B., Perez, E., 2016. Understanding the fragmentation pattern of marine plastic debris. Environ. Sci. Technol. 50, 5668-5675.

Van Cauwenberghe, L., Claessens, M., Vandegehuchte, M.B., Janssen, C.R., 2015. Microplastics are taken up by mussels (Mytilus edulis) and lugworms (Arenicola marina) living in natural habitats. Environ. Pollut. 199, 10-17.

Vendel, A.L., Bessa, F., Alves, V.E.N., Amorim, A.L.A., Patricio, J., Palma, A.R.T., 2017. Widespread microplastic ingestion by fish assemblages in tropical estuaries subjected to anthropogenic pressures. Mar. Pollut. Bull. 117, 448-455.
Welden, N.A.C., Cowie, P.R., 2016. Long-term microplastic retention causes reduced body condition in the langoustine, Nephrops norvegicus. Environ. Pollut. 218, 895-900.

van Wezel, A., Caris, I., Kools, S., 2015. Release of primary microplastics from consumer products to wastewater in The Netherlands. Environ. Toxicol. Chem. 35, 1627-1631. Wilber, R.J., 1987. Plastic in the North Atlantic. Oceanus 30, 61-68.

Woodall, L.C., Sanchez-Vidal, A., Canals, M., Paterson, G.L., Coppock, R., Sleight, V., Calafat, A., Rogers, A.D., Narayanaswamy, B.E., Thompson, R.C., 2014. The deep sea is a major sink for microplastic debris. R. Soc. Open Sci. 1, 140317.

Wright, S.L., Thompson, R.C., Galloway, T.S., 2013. The physical impacts of microplastics on marine organisms: a review. Environ. Pollut. 178, 483-492. 